\title{
Nutrient resorption efficiency of three tree species in Beijing plain afforestation and its C:N:P stoichiometry
}

\author{
Yuanhao Wu ${ }^{1,2}$, Jun Jiang ${ }^{1}=$, Beibei Chen', Yucun Hu$^{2}$
}

Wu Y., Jiang J., Chen B., Hu Y., 2020. Nutrient resorption efficiency of three tree species in Beijing plain afforestation and its $\mathrm{C}: \mathrm{N}: \mathrm{P}$ stoichiometry. Ann. For. Res. 63(2): 91-102.

Abstract Elucidating variability in nutrient resorption and carbon (C), nitrogen $(\mathrm{N})$ and phosphorus $(\mathrm{P})$ stoichiometry is important for holistically understanding plant approaches to nutrient adaption. However, the patterns of these phenomena in afforested regions of the Beijing Plain have been ignored. Herein, we assessed patterns of leaf and litter $\mathrm{C}, \mathrm{N}$, and $\mathrm{P}$ stoichiometry and nutrient resorption in Robinia pseudoacacia L., Ailanthus altissima (Mill.) Swingle, and Salix matsudana Koidz. forests in afforested areas in Beijing, China. We found that the plantation growth of $R$. pseudoacacia and S. matsudana was mainly limited by $\mathrm{P}$ nutrients. Both the $\mathrm{N}$ and $\mathrm{P}$ in the fresh leaves of $R$. pseudoacacia were significantly higher than those in the fresh leaves of $S$. matsudana and $A$. altissima, indicating that the $\mathrm{N}$ resorption efficiency (NRE) of $R$. pseudoacacia was higher. However, the $\mathrm{P}$ resorption efficiency (PRE) was significantly correlated with the leaf $\mathrm{P}$ nutrients in the R. pseudoacacia and A. altissima forests. Except for the significant correlation between the $\mathrm{N}$ content of fresh leaves and the AN content in soil, there were no significant correlations between the leaf $\mathrm{C}, \mathrm{N}$ and $\mathrm{P}$ contents and the contents of these nutrients in the soil. These results suggested that of the factors studied, leaf P stoichiometry and PRE were more responsive indicators of the afforestation area on the Beijing Plain. Together, our data indicated that $\mathrm{P}$ deficiency is an important factor for the forests on the Beijing Plain and that the ability of afforested areas to adapt to barren land through nutrient resorption is gradually weakened and the $\mathrm{N}$ and $\mathrm{P}$ nutrient preservation ability is reduced over time. We thus clarified the nutrient resorption and leaf $\mathrm{P}$ and $\mathrm{N}$ patterns for the three forests studied. The findings have important implications for the application of $\mathrm{P}$ fertilizer, which must be conducted in a timely fashion to ensure that nutrient addition meets the nutritional needs of the plants.

Keywords: Nutrient resorption, leaf, litter, stoichiometry, Beijing plain afforestation

Addresses: ${ }^{1}$ Research Center of Forest Management Engineering of State Forestry and Grassland Administration, Beijing Forestry University, Beijing, China| ${ }^{2}$ School of Soil and Water Conservation, Beijing Forestry University, Beijing, China.

$\square$ Corresponding Author: Jun Jiang (jiang@bjfu.edu.cn).

Manuscript received July 24, 2020; revised December 21, 2020; accepted December 24, 2020. 


\section{Introduction}

Afforestation plays an important role in wind prevention, sand fixation, and cropland protection (Paul et al. 2002). Since the five years, afforestation established since 2012, account for up to 78000 ha of total plain afforestation area in Beijing (Liu et al. 2015). Robinia pseudoacacia, Ailanthus altissima, and Salix matsudana are the most important tree species in plain afforestation, and account for up to $50 \%$ of the total plain area in Beijing. However, R. pseudoacacia, A. altissima, and $S$. matsudana stands (i.e., those planted in 2012) have undergone slow degradation due to abiotic factors, such as snow, human activity, and desertification, as well as biotic factors, such as issues caused by being planted in pure stands and problems with regeneration (Wang et al. 2017). To date, the mechanism has not yet been revealed.

Leaf stoichiometry can be employed to effectively assess plant nutrient limitations in the growth and development of forests (Koerselman \& Meuleman 1996, Yan et al. 2017), and nutrient resorption represents an essential mechanism with profound influences on many processes, including plant growth, decomposition, and resource use efficiency, and plays a key role in the function and dynamics of ecosystems (Güsewell 2004). Particularly in nutrient-poor forest environments, leaf nutrient resorption is crucial for productive growth and element cycling (Cleveland et al. 2013). Therefore, both leaf stoichiometry and nutrient resorption may yield new insights into plant nutrient cycling, which may help to understand on the strategy of plant nutrient adaption.

Nutrient stoichiometry and resorption typically vary among tree species within forests due to nutrient uptake and utilization strategies and harsh environmental conditions (Amazonas et al. 2011). How tree nutrient stoichiometry and resorption vary with different species has been the subject of numerous studies, with inconsistent results (Pugnaire \& Chapin 1993, Elser et al. 2010, Zhao et al. 2018). For example, Zhang et al. (2014) found that some evergreen trees increase the efficiency of nutrient resorption and utilization by reducing the nitrogen content in the litter leaves, so as to adapt to the harsh environment in Qinghai Tibet Plateau, while Yan et al. (2015) found Herbaceous plants have high resorption ability to the main elements which restrict their growth in dry hot valley.

Plants that exhibit robust nutrient resorption activity are better able to utilize their own internal nutrient supplies without losing them via litter. However, as essential nutrients, including $\mathrm{C}, \mathrm{N}$ and $\mathrm{P}$, can also limit plant growth (Elser et al. 2003). The $\mathrm{N}$ resorption efficiency (NRE) and P resorption efficiency (PRE) are related to the nutrient demand of plant (Sun et al. 2016), and NRE and PRE usually affects the normal uptake of mineral elements in plants and further causes the plants abnormal growth and development (Du et al. 2017). Effective resorption of the mineral elements before leaves are shed provides an important mechanism for conservation. Moreover, most researches have inconsistencies may result from element-specific (Wang et al. 2015), or species-specific responses (Gyenge \& Fernández 2014). Therefore, it is an important aspect to measure the relationship between stoichiometry and nutrient resorption to reveal the possible survival mechanism due to nutrient limitation for a given species.

Apart from tree species, one of conclusions is that organisms must change their $\mathrm{C}: \mathrm{N}: \mathrm{P}$ stoichiometry as a function of their growth rate (Sterner \& Elser 2002, Tessier \& Raynal 2003). Plant growth does not only rely on a single nutrient's availability, but on the balance between multiple nutrients (Vitousek 2003). This is the case, for instance, $\mathrm{C}: \mathrm{N}$ and $\mathrm{C}: \mathrm{P}$ of plant leaves largely reflect the competitiveness and adaptability of plants to poor environment, and $\mathrm{N}: \mathrm{P}$ can be used as the main basis for 
evaluating the nutrient limitation of plants (Ågren 2008). Thus, ecological stoichiometry has provided an integrative solution to measure changes in $\mathrm{C}, \mathrm{N}$ and $\mathrm{P}$ within a plant at a given time (Kobe et al. 2005). In Beijing plain, nutrient deficiency and imbalance are serious problems (Cui et al. 2015), and it is important to understand the effects of leaf nutrient stoichiometry and nutrient resorption with different afforestation forests.

In this study, we examined leaf $\mathrm{C}, \mathrm{N}$, and $\mathrm{P}$ stoichiometric patterns and nutrient resorption in $R$. pseudoacacia, A. altissima, and $S$. matsudana forests in the Beijing Plain afforestation area. In addition, we assessed how tree species and leaf and litter stoichiometry influence $\mathrm{C}, \mathrm{N}$ and $\mathrm{P}$ stoichiometry and nutrient resorption with the goal of assessing the following: (1) the leaf and litter $\mathrm{C}, \mathrm{N}, \mathrm{P}$ stoichiometry patterns and $\mathrm{N}$ and $\mathrm{P}$ resorption efficiency in $R$. pseudoacacia, A. altissima, and $S$. matsudana forests in the Beijing Plain afforestation ecosystems; (2) nutrient resorption, with different forests, also significantly impact on $\mathrm{C}, \mathrm{N}$, and $\mathrm{P}$ stoichiometry; (3) the elements that serve as relatively limiting nutrients in these forests. Together, these analyses can provide details regarding key nutrient factors critical for the afforestation of plains, and the results should provide novel insights that allow us to better understand afforested areas in light of nutrient limitations, and also provide a theoretical basis for forest management on the Beijing Plain.

\section{Material and methods}

\section{Study site}

R. pseudoacacia, A. altissima, and S. matsudana are three broad-leaved of the family Fabaceae Lindl., Simaroubaceae DC. and Salicaceae Mirb., respectively. Following its discovery as a living species, the species has been planted in numerous locations throughout the Beijing, with a wide range of mean annual temperature. Since 2012, the species have been planted along eastern and northern of Beijing for controlling erosion and reducing wind damage under "Beijing plain afforestation program" (Wang et al. 2017). R. pseudoacacia, A. altissima, and $S$. matsudana becomes the main species of shelterbelts in Beijing.

The study was conducted in Beijing $\left(39^{\circ} 30^{\prime} 13.99^{\prime \prime} \mathrm{N}, 116^{\circ} 15^{\prime} 26.54^{\prime \prime}\right.$ E) (Figure 1). It features $30-45 \mathrm{~m}$ above sea level. The annual average temperature is $11.5{ }^{\circ} \mathrm{C}$, the precipitation is $568.9 \mathrm{~mm}$, the rainfall is mainly concentrated in July-September, and humidity of $63-68 \%$. Before the implementation of the plain forest construction, the study area was the sand wasteland, the lotus root land of potholes and the land for conversion of farmland to forest (Zheng et al. 2018). Its own land force is relatively weak compared with the natural forest, mainly distributed in light loamy brown tide soil and sandy loam soil, and the $\mathrm{pH}$ value is 8.8-9.1.

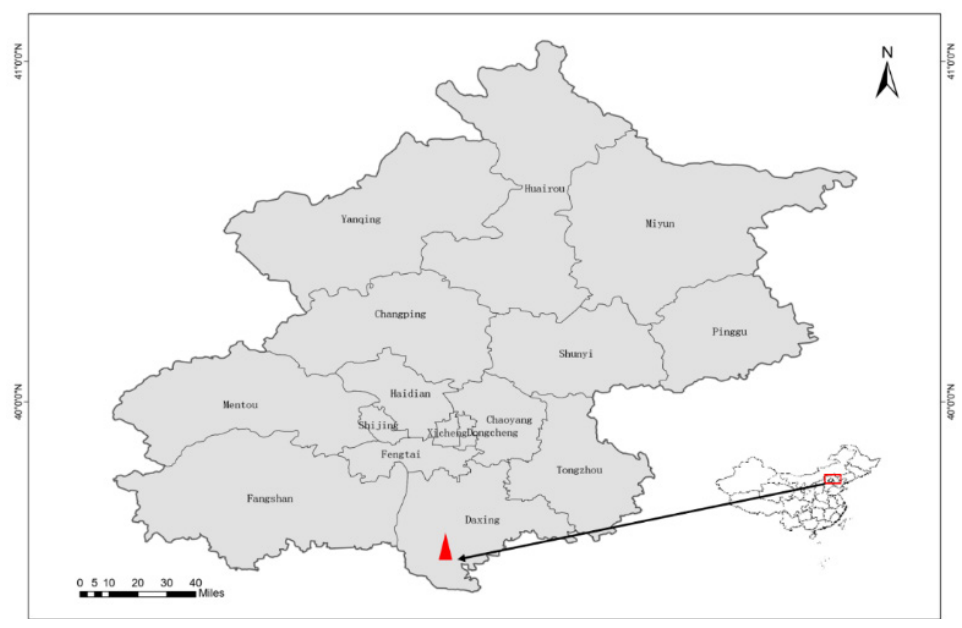

Figure 1 Location of the forest plots studied in Beijing of China 


\section{Experiment design and sample collection}

The study site was the pioneer area to plant the $R$. pseudoacacia, A. altissima, and $S$. matsudana in plain Beijing. In late August 2019, R. pseudoacacia, A. altissima, and $S$. matsudana forests were investigated in Daxing forest farm. These forests were with similar site conditions and less human activity since afforested in 2012. Based on a comprehensive review of the Beijing plain plantations, we selected the study site that reflected the mean elevation, aspect, and soil conditions within the plantations. All sites had similar soils, climate, land-use history. Each tree species had three replicates with similar terrain characteristics. Three replicates of plot, with the site conditions, such as landform, altitude, soil type and slope, were nearly identical, $20 \times 20 \mathrm{~m}$, were established in each tree species. The diameter at breast height $(\mathrm{DBH})$ was measured for all trees in each plot
(Table 1). Based on DBH, five standard trees were randomly selected in each plot, which were selected for collecting leaves. Fully expanded leaves from the upper and outer part of tree crowns were sampled, and thoroughly mixed to homogenize a sample. Three $1 \times 1 \mathrm{~m}$ litter traps (made of nylon mesh) per plot were fixed $1.0 \mathrm{~m}$ above the ground. Leaf litter was collected in late November 2019. The litter in the samples was harvested, weighed after being mixed, and taken back to the laboratory for drying at $80{ }^{\circ} \mathrm{C}$ in an oven. The leaves and litter of each forest were collected using a plant crusher and the impurities were removed, the purity of litter was guaranteed. Five soil cores (2.5 $\mathrm{cm}$ in diameter) per plot were randomly collected from 0 to $20 \mathrm{~cm}$ depth following removal of understory plants and surface litter, and thoroughly mixed to homogenize a sample. The mixed soil sample of topsoil was collected from that of litter sample using the soil drilling method and taken back to the laboratory.

Table 1 Basic status of sampling sites and trees

\begin{tabular}{lccccccc}
\hline Forest type & Elevation $(\mathrm{m})$ & $\begin{array}{c}\text { Slope } \\
\left({ }^{\circ}\right)\end{array}$ & $\begin{array}{c}\text { Age } \\
(\mathrm{a})\end{array}$ & $\begin{array}{c}\text { Mean DBH } \\
(\mathrm{cm})\end{array}$ & $\begin{array}{c}\text { Mean tree } \\
\text { height }(\mathrm{m})\end{array}$ & $\begin{array}{c}\text { Density } \\
\left(\text { tree } / \mathrm{hm}^{2}\right)\end{array}$ & $\begin{array}{c}\text { Coverage } \\
(\%)\end{array}$ \\
\hline R. pseudoacacia & 40 & 6 & 7 & $13.62 \pm 1.03$ & $5.8 \pm 0.54$ & $678 \pm 25$ & 0.78 \\
A. altissima & 41 & 6 & 7 & $13.3 \pm 0.95$ & $6.9 \pm 0.76$ & $589 \pm 88$ & 0.85 \\
S. matsudana & 45 & 6 & 7 & $17.1 \pm 1.21$ & $11.1 \pm 1.01$ & $633 \pm 54$ & 0.80 \\
\hline
\end{tabular}

Notes: Values are presented as the mean \pm standard deviation (SD). Each tree species represents an average value across three replicate plots, five soil samples per plot were randomly collected $(n=15)$.

\section{Chemical measurements}

The $\mathrm{C}$ and $\mathrm{N}$ concentration were determined for each sample using an autoanalyzer (Kjeltec 2300 Analyzer Unit, Foss, Sweden). Leaf and litter organic carbon and soil organic carbon (SOC) was determined with wet oxidation by sulfuric acid and potassium dichromate and back titration with ferrous sulfate. The total $\mathrm{N}$ (TN) was measured using the semi-micro Kjeldahl method with a Kjeldahl Auto-analyzer (KDN-102C, Shanghai, China), total P (TP) concentration was measured using the $\mathrm{HNO}_{3}$
digest-Mo-Sb antispectrophotography method using a spectrophotometer (UV-2102 PCS, Shanghai, China). Available $\mathrm{P}$ concentration (AP) was determined with molybdate blue colorimeter after extraction with $0.5 \mathrm{M}$ sodium bicarbonate, alkali-hydrolyzable nitroge was measured using Alkaline hydrolysis diffusion method. The ecological stoichiometric ratios of $\mathrm{C}, \mathrm{N}$ and $\mathrm{P}$ were calculated as $\mathrm{C}$ vs. total $\mathrm{N}$ $(\mathrm{C}: \mathrm{N}), \mathrm{C}$ vs. total $\mathrm{P}(\mathrm{C}: \mathrm{P})$ and total $\mathrm{N}$ vs. total $\mathrm{P}(\mathrm{N}: \mathrm{P})$. 


\section{Data analysis}

Nutrient resorption efficiency (NuRE) was defined as the proportional withdrawal of a nutrient during senescence and was calculated by equation:

$\mathrm{NuRE}=\left(1-\frac{\mathrm{X}_{\text {litter }}}{\mathrm{X}_{\text {leaf }}} \times \mathrm{MLCF}\right) \times 100 \%$, where

NuRE is $\mathrm{N}$ or $\mathrm{P}$ resorption efficiency, $\mathrm{X}_{\text {leaf }}$ and $\mathrm{X}_{\text {litter }}$ represent $\mathrm{N}$ or $\mathrm{P}$ concentration (mass based) in leaf and litter respectively, and where MLCF is mass loss correction factor and about 0.784 for deciduous broadleaved species (Vergutz et al. 2012). Each tree species represents an average value across three replicate plots $(n=15)$, five soil samples per plot were randomly collected, i.e., three plots repeats $\times$ five soil samples. Values are presented as the mean \pm standard deviation (SD). One-way ANOVA was used to test the differences of leaf $\mathrm{C}, \mathrm{N}, \mathrm{P}$ stoichiometry and nutrient resorption among three forests, and a least significant difference post hoc test was used to test for significant differences at the 0.05 and 0.01 levels, p-values $<0.05$ and $<0.01$ were considered statistically significant, respectively. Pearson correlation analyses were performed to test the relationships between leaf and litter stoichiometry and nutrient resorption and soil nutrients of forests. Regression analyses were used to examine the relationships between tree stoichiometry, nutrient resorption and leaf $\mathrm{N}$ and $\mathrm{P}$ stoichiometry. All analyses were performed using by SigmaPlot 10.0 (Systat Software, Inc., Richmod, CA, USA). Statistically significant differences were recognized at $\mathrm{p}<0.05$.

\section{Results}

\section{Variations in leaf and litter C, N, P contents and stoichiometry of three forests}

Leaf C, N, P contents differed significantly among three plantations (Table 2). The highest fresh leaf $\mathrm{N}$ and $\mathrm{P}$ contents values were obtained in $R$. pseudoacacia, respectively $26.32 \mathrm{~g} \cdot \mathrm{kg}^{-1}$ and $1.56 \mathrm{~g} \cdot \mathrm{kg}^{-1}$, while the highest fresh leaf C contents values $\left(457.55 \mathrm{~g} \cdot \mathrm{kg}^{-1}\right)$ were obtained in S. matsudana. C, N, P stoichiometry of fresh leaves and litters showed significant differences among three plantations (Table 3). The fresh leaf $\mathrm{C}: \mathrm{N}$ and $\mathrm{C}: \mathrm{P}$ ratios were higher in the $S$. matsudana plantation than in the other plantations. The N:P ratio of $R$. pseudoacacia was significantly elevated relative to that in the fresh leaves in the three forests. In contrast, the litter $\mathrm{C}: \mathrm{N}, \mathrm{C}: \mathrm{P}$, and $\mathrm{N}: \mathrm{P}$ ratios were highest for $S$. matsudana, with values of $25.41,868.7$ and 16.64 , respectively.

Table 2 C, N, P contents of fresh leaf and litter in three tree species

Type Tree species $\quad \mathrm{C}$ content $\left(\mathrm{g} \cdot \mathrm{kg}^{-1}\right) \quad \mathrm{N}$ content $\left(\mathrm{g} \cdot \mathrm{kg}^{-1}\right) \quad \mathrm{P} \mathrm{content}\left(\mathrm{g} \cdot \mathrm{kg}^{-1}\right)$

\begin{tabular}{llccc}
\hline \multirow{2}{*}{ Fresh leaf } & R. pseudoacacia & $378.12 \pm 18.21 \mathrm{~b}$ & $26.32 \pm 3.44 \mathrm{a}$ & $1.56 \pm 0.04 \mathrm{a}$ \\
& A. altissima & $342.27 \pm 9.34 \mathrm{c}$ & $16.64 \pm 5.38 \mathrm{~b}$ & $1.02 \pm 0.09 \mathrm{a}$ \\
& S. matsudana & $401.81 \pm 21.55 \mathrm{a}$ & $15.26 \pm 7.77 \mathrm{~b}$ & $0.98 \pm 0.05 \mathrm{~b}$ \\
\hline \multirow{2}{*}{ Litter } & R. pseudoacacia & $337.81 \pm 19.33 \mathrm{c}$ & $17.34 \pm 1.89 \mathrm{~b}$ & $1.41 \pm 0.04 \mathrm{a}$ \\
& A. altissima & $411.17 \pm 12.17 \mathrm{~b}$ & $20.92 \pm 1.31 \mathrm{a}$ & $1.01 \pm 0.01 \mathrm{~b}$ \\
& S. matsudana & $457.55 \pm 9.74 \mathrm{a}$ & $15.01 \pm 2.07 \mathrm{c}$ & $0.42 \pm 0.03 \mathrm{c}$ \\
\hline
\end{tabular}

Notes: Different lowercase letters in the same column indicate significant difference at $\mathrm{p}<0.05$ level. Values are presented as the mean \pm standard deviation (SD). Each tree species represents an average value across three replicate plots, five soil samples per plot were randomly collected $(n=15)$. 
Table 3 C, N, P stoichiometry of fresh leaf and litter in three tree species

\begin{tabular}{llccc}
\hline \multirow{2}{*}{ Type } & Tree species & C: $\mathrm{N}$ & C:P & N:P \\
\hline \multirow{2}{*}{ Fresh leaf } & R. pseudoacacia & $14.53 \pm 1.87 \mathrm{c}$ & $512.33 \pm 31.44 \mathrm{c}$ & $25.18 \pm 1.88 \mathrm{a}$ \\
& A. altissima & $18.36 \pm 2.34 \mathrm{~b}$ & $640.28 \pm 28.17 \mathrm{~b}$ & $11.94 \pm 1.32 \mathrm{c}$ \\
& S. matsudana & $23.22 \pm 3.13 \mathrm{a}$ & $651.22 \pm 44.23 \mathrm{a}$ & $18.76 \pm 2.11 \mathrm{~b}$ \\
\hline \multirow{2}{*}{ Litter } & R. pseudoacacia & $19.82 \pm 1.96 \mathrm{~b}$ & $508.19 \pm 47.29 \mathrm{c}$ & $13.54 \pm 2.36 \mathrm{~b}$ \\
& A. altissima & $20.8 \pm 4.44 \mathrm{~b}$ & $536.79 \pm 27.24 \mathrm{~b}$ & $14.35 \pm 1.28 \mathrm{~b}$ \\
& S. matsudana & $25.41 \pm 3.12 \mathrm{a}$ & $868.7 \pm 26.45 \mathrm{a}$ & $16.64 \pm 3.18 \mathrm{a}$ \\
\hline
\end{tabular}

Note Different lowercase letters in the same column indicate significant difference at $\mathrm{p}<0.05$ level. Values are presented as the mean \pm standard deviation (SD). Each tree species represents an average value across three replicate plots, five soil samples per plot were randomly collected $(n=15)$.

\section{Nutrient resorption efficiency}

The mean NRE values of the three forests, which showed the $\mathrm{N}$ resorption activities of the three plantations, were ordered as follows: $R$. pseudoacacia $>$ S. matsudana $>$ A. altissima (Figure 2). The highest NRE, which ranged between $50.34 \%$ and $73.47 \%$, occurred in the $R$. pseudoacacia plantation $(\mathrm{p}<0.05)$. In contrast, the $S$. matsudana plantation had a PRE value ranged between $43.26 \%$ and $52.62 \%$, which was much higher than that in A. altissima, and R. pseudoacacia plantations with corresponding PRE value of $22.34 \%$ and $18.70 \%$, respectively $(\mathrm{p}<0.05)$.

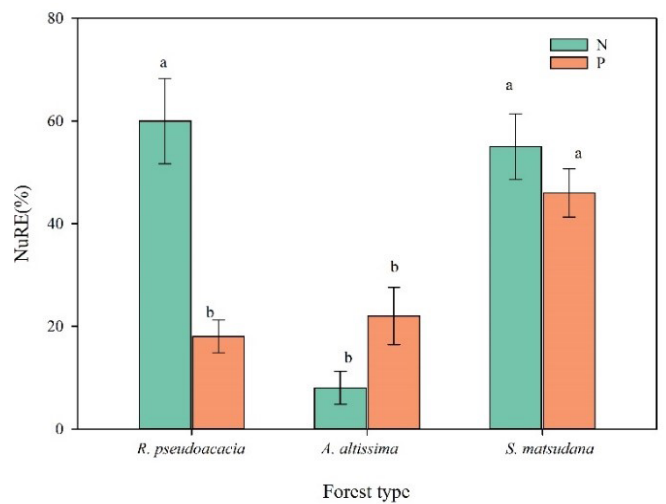

Figure $2 \mathrm{~N}$, P resorption efficiency in three forests. Different lowercase letters indicate significant differences among different forests $(\mathrm{p}<0.05)$

\section{Effects of nutrient resorption efficiency of fresh leaf and litter and stoichiometry in three forests}

Nutrient resorption efficiency of fresh leaf and litter were also related to $\mathrm{C}, \mathrm{N}$, and $\mathrm{P}$ stoichiometry in three forests (Table 4). The NRE was positively significantly associated with litter $\mathrm{C}: \mathrm{N}$ and significantly negatively correlated with litter N:P in the $R$. pseudoacacia forest $(\mathrm{p}<0.01)$. There was a negative correlation between NRE and N:P in litter of $A$. altissima, and negative correlations were observed between PRE and C:N, and $\mathrm{C}: \mathrm{P}$ in fresh leaf of $A$. altissima $(\mathrm{p}<0.05)$.In addition, NRE positively correlated with $\mathrm{C}: \mathrm{N}$, while negatively correlated with $\mathrm{N}: \mathrm{P}$ in litter of $S$. matsudana $(\mathrm{p}<0.05)$. In contrast, PRE was positively associated with $\mathrm{C}: \mathrm{N}$ in fresh leaf of $S$. matsudana $(\mathrm{p}<0.05)$. No significant correlations were observed in other cases. The leaf $\mathrm{N}$ contents of the three plantations displayed no significant relationship with the NRE (Figure 3). By contrast, PRE was correlated with leaf $\mathrm{P}$ nutrient in $R$. pseudoacacia and $S$. matsudana plantations, except $A$. altissima plantations (Figure 4). The average AN in $R$. pseudoacacia forest was significantly higher than that in A. altissima and $S$. matsudana forest (Table 5). The TN in the fresh leaves and AN in the soil were 
significantly positively correlated (Table $6, \mathrm{p}<0.05$ ), showed nonsignificant differences with the soil while the contents of $\mathrm{C}, \mathrm{N}$ and $\mathrm{P}$ in the litters nutrient contents.
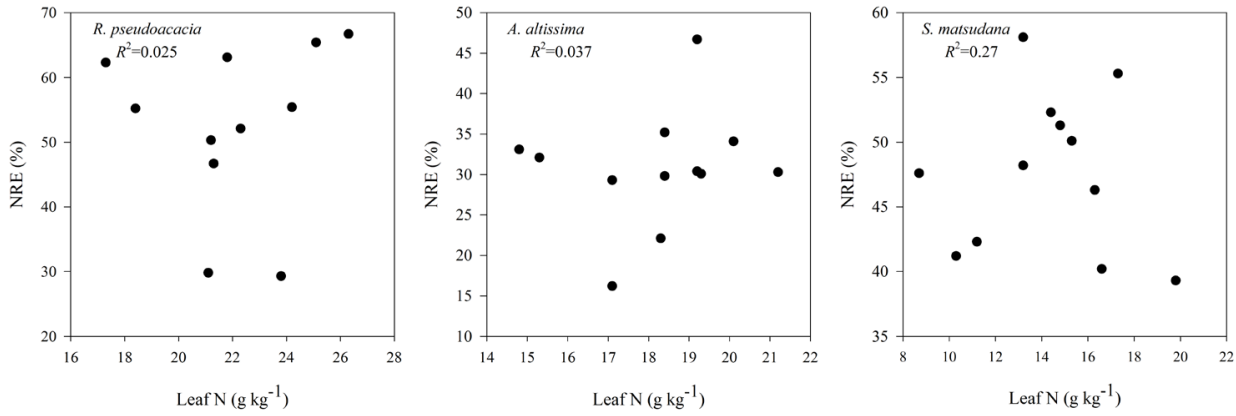

Figure 3 Relationships between N resorption efficiency (NRE) and leaf stoichiometry
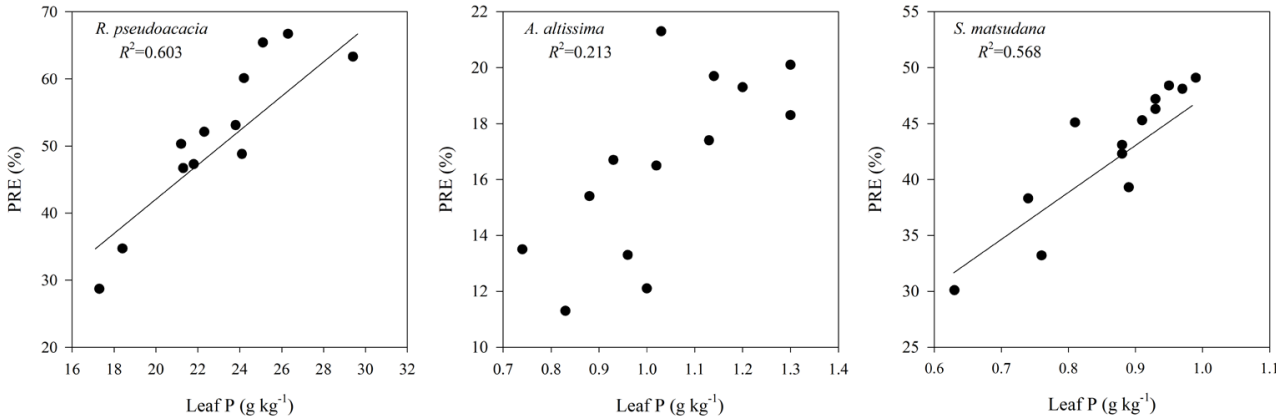

Figure 4 Relationships between P resorption efficiency (PRE) and leaf stoichiometry

Table 4 Correlations between N, P resorption efficiency (RE) of fresh leaf and litter and C,

$\mathrm{N}, \mathrm{P}$ stoichiometric characteristics in three tree species

\begin{tabular}{llllllll}
\hline & & \multicolumn{3}{c}{ Fresh leaf } & \multicolumn{3}{c}{ Litter } \\
\hline Tree species & RE & C:N & C:P & N:P & C:N & C:P & N:P \\
\hline \multirow{2}{*}{ R. pseudoacacia } & NRE & -0.255 & -0.023 & -0.093 & $0.877^{* *}$ & 0.307 & $-0.863^{* *}$ \\
& PRE & 0.316 & 0.116 & -0.352 & -0.443 & -0.06 & 0.443 \\
A. altissima & NRE & -0.612 & -0.323 & 0.093 & 0.141 & -0.153 & $-0.618^{*}$ \\
& PRE & $-0.667^{*}$ & $-0.668^{*}$ & -0.523 & -0.04 & -0.302 & -0.323 \\
S. matsudana & NRE & -0.135 & -0.122 & 0.634 & $0.732^{*}$ & 0.052 & $-0.693^{*}$ \\
& PRE & $0.501^{*}$ & 0.374 & 0.102 & -0.087 & 0.371 & 0.061 \\
\hline
\end{tabular}

Notes: *indicates $\mathrm{P}<0.05 ; * *$ indicates $\mathrm{p}<0.01$. Each tree species represents an average value across three replicate plots, five soil samples per plot were randomly collected $(n=15)$. 
Table 5 Soil properties of three different forests sample plots

\begin{tabular}{lccccc} 
Plantation type & SOC $\left(\mathrm{g} \cdot \mathrm{kg}^{-1}\right)$ & $\mathrm{TN}\left(\mathrm{g} \cdot \mathrm{kg}^{-1}\right)$ & $\mathrm{TP}\left(\mathrm{g} \cdot \mathrm{kg}^{-1}\right)$ & $\mathrm{AN}\left(\mathrm{mg} \cdot \mathrm{kg}^{-1}\right)$ & $\mathrm{AP}\left(\mathrm{mg} \cdot \mathrm{kg}^{-1}\right)$ \\
\hline R. pseudoacacia & $37.57 \pm 10.03 \mathrm{a}$ & $1.72 \pm 0.58 \mathrm{a}$ & $1.09 \pm 0.05 \mathrm{a}$ & $214.93 \pm 31.68 \mathrm{a}$ & $47.51 \pm 17.73 \mathrm{a}$ \\
A. altissima & $23.14 \pm 7.15 \mathrm{a}$ & $1.53 \pm 0.52 \mathrm{a}$ & $1.64 \pm 0.02 \mathrm{a}$ & $113.87 \pm 40.01 \mathrm{~b}$ & $29.41 \pm 20.83 \mathrm{a}$ \\
S. matsudana & $22.92 \pm 4.06 \mathrm{a}$ & $1.95 \pm 0.52 \mathrm{a}$ & $1.07 \pm 0.03 \mathrm{a}$ & $101 \pm 32.18 \mathrm{~b}$ & $24.11 \pm 14.53 \mathrm{a}$ \\
\hline
\end{tabular}

Notes: SOC, soil organic carbon; TN, total nitrogen; TP, total phosphorus; AN, alkali-hydrolyzable nitrogen; AP, available phosphorus. Different lowercase letters in the same column indicate significant difference at $\mathrm{P}<0.05$ level. Values are presented as the mean \pm standard deviation (SD). Each tree species represents an average value across three replicate plots, five soil samples per plot were randomly collected $(n=15)$.

Table 6 Pearson's correlation coefficients between nutrient contents in leaves, litters and soil properties (SOC, TN, TP, AN, AP and $\mathrm{pH}$ )

\begin{tabular}{llllllll}
\hline Type & $\begin{array}{l}\text { Soil } \\
\text { properties }\end{array}$ & SOC & TN & TP & AN & AP & pH \\
\hline \multirow{3}{*}{ Fresh leaf } & SOC & 0.131 & 0.336 & -0.238 & -0.092 & 0.231 & 0.036 \\
& TN & -0.094 & -0.242 & -0.114 & $0.621^{*}$ & 0.366 & 0.057 \\
& TP & -0.035 & -0.219 & -0.069 & 0.245 & 0.279 & 0.277 \\
\hline \multirow{2}{*}{ Litter } & SOC & 0.211 & -0.057 & -0.213 & -0.136 & -0.037 & 0.013 \\
& TN & -0.367 & 0.331 & 0.083 & 0.075 & -0.493 & 0.213 \\
& TP & -0.154 & -0.146 & 0.037 & 0.130 & 0.348 & 0.352 \\
\hline
\end{tabular}

Notes: *indicates $\mathrm{p}<0.05$. Notes: SOC, soil organic carbon; TN, total nitrogen; TP, total phosphorus; AN, alkalihydrolyzable nitrogen; AP, available phosphorus. Each tree species represents an average value across three replicate plots, five soil samples per plot were randomly collected $(n=15)$.

\section{Discussion}

Plants and soil are closely linked, and their interactions have important implications for in a plant-soil system due to variations in soil nutrient availability and plant nutrient status. In our study, no significant correlation between the contents of $\mathrm{C}, \mathrm{N}$ and $\mathrm{P}$ in the fresh leaves and litter of three trees was detected, with the exception of the $\mathrm{N}$ in the fresh leaves and the in the soil; this was in contrast to some previous studies that found that plant species, local climate and soil nutrients may affect the $\mathrm{N}$ and $\mathrm{P}$ contents in plant leaves (Elser et al. 2010, Vergutz et al. 2012). In addition, because the soil nutrients showed nonsignificant trends among the different forest types and the climate, elevation and slope of the sample plots were basically the same, the total soil nutrients in the study area were not the primary reason for the differences in nutrient contents in the different plantations. The availability of nutrients, especially AN, was the main factor controlling the $\mathrm{N}$ content in the fresh leaves. This suggested that higher supply of $\mathrm{N}$ from leaf caused the accumulation of $\mathrm{N}$ in soil (Reich \& Oleksyn 2004). Therefore, the supply of $\mathrm{N}$ becomes increasingly important for the sustainability of plantations over time. The leaf $\mathrm{N}$ and $\mathrm{P}$ of $R$. pseudoacacia were significantly higher than $A$. altissima and $S$. matsudana, because $R$. pseudoacacia was a Leguminosae plants have strong ability of nitrogen fixation, it could improve the soil $\mathrm{N}$ availability and nutrient cycling (Houlton et al. 2008). This was consistent with $\mathrm{Zhu}$ et al. (2010), who reported that leguminous plants have higher leaf nitrogen content. We thus posit that replacing trees used for afforestation with 
species capable of $\mathrm{N}$ fixation or that are less competitive can benefit overall soil fertility and productivity.

Leaf nutrient resorption is a vital constituent in plant-soil system to improve nutrient cycling especially in nutrient-poor environment (Vergutz et al. 2012). Nutrient resorption efficiency differs by species, and the resorption characteristics of the same species in different habitats are also different. The NRE was higher in the $R$. pseudoacacia forest than in the other forests, whereas the PRE was higher in the S. matsudana forest. This is because of the biological nitrogen fixation capacity of leguminous species and because the overall $\mathrm{N}$ cycle of these species differs greatly from that of non-nitrogen-fixing plants (Boddey et al. 2000), resulting in a significant difference between the $R$. pseudoacacia forest and the other two forests. According to the study on nutrient resorption rate of various terrestrial plants by Vergutz et al. (2012) on a global scale, the results showed that $\mathrm{N}$ and $\mathrm{P}$ had high nutrient resorption rates (respectively $62.1 \%, 64.9 \%$ ). However, in our study, the NRE and PRE of the three forests in Beijing plain were lower than the above results. Some studies have suggested that nutrient transfer and resorption may only be an inherent feature of the species, and genetic differences may be the main factor determining nutrient resorption (Killingbeck 1996, Luyssaert et al. 2005). Moreover, due to the different habitats in the study area, the plant nutrient resorption rate showed specificity (Reed et al. 2012).

Previous studies have found that the $C: N$ and $\mathrm{N}: \mathrm{P}$ ratios in litter are often negatively correlated with the litter decomposition rate (Vitousek et al. 1994). The results of this study showed that the $\mathrm{C}: \mathrm{N}$ and N:P ratios of $R$. pseudoacacia were lower than those of $\mathrm{S}$. matsudana and $A$. altissima, indicating that the decomposition rate of $R$. pseudoacacia was the fastest among the three forests. In addition, the higher the $\mathrm{C}: \mathrm{N}$ and $\mathrm{C}: \mathrm{P}$ of fresh leaves is, the stronger the competition ability and adaptability to poor environments; moreover, the content of $\mathrm{N}$ in fresh $R$. pseudoacacia leaves was much higher than that in the other two species, and the PRE was the lowest. This suggested that mature $R$. pseudoacacia can increase the $\mathrm{N}$ content and reduce the $\mathrm{C}: \mathrm{N}$ and $\mathrm{N}: \mathrm{P}$ ratios in their leaves through nitrogen fixation. This ability helped to accelerate the decomposition rate and reduce the resorption rate of $\mathrm{P}$, promoting the recycling efficiency of $\mathrm{P}$ in the soil.

In this study, the NRE of $R$. pseudoacacia was significantly positively correlated with the $\mathrm{C}: \mathrm{N}$ ration and negatively correlated with the $\mathrm{N}: \mathrm{P}$ ratio, which was consistent with the results showing higher $\mathrm{N}$ and $\mathrm{P}$ utilization efficiency by $R$. pseudoacacia. For A. altissima, there was a significant negative correlation between the NRE and fresh leaf N:P ratio $(\mathrm{p}<0.05)$ and the PRE was negatively correlated with the $\mathrm{C}: \mathrm{N}$ and $\mathrm{C}: \mathrm{P}$ ratios of fresh leaves. The results showed that the effect of PRE was greater than that of NRE on the stoichiometric characteristics, which was consistent with the conclusions of Vitousek et al. (1994) that the growth of $A$. altissima was limited by $\mathrm{P}$. The $\mathrm{P}$ content was not completely absorbed in the $R$. pseudoacacia or A. altissima forests, indicating that the ability of mature $R$. pseudoacacia and A. altissima on the Beijing Plain to adapt to barren sites through nutrient resorption was relatively weak and that the ability for $\mathrm{N}$ and $\mathrm{P}$ nutrient conservation and self-transfer was low. This phenomenon suggests that when plant growth is restricted by certain elements due to environmental nutrient imbalance, plants tend to have a higher resorption efficiency of those restrictive elements, thus forming a feedback loop with the environment. This finding supported the "relative resorption hypothesis" that plants would resorb proportionally more $\mathrm{N}$ or $\mathrm{P}$ when plants are growing under $\mathrm{N}$ or P-limited conditions (Güsewell 2005). Therefore, the relative changes in NRE and PRE probably reflect the variation in nutrient retrieval strategies among species in response 
to environments (Rejmánková 2005). Based on our data, PRE showed a curve correlation leaf $\mathrm{P}$ in R. pseudoacacia and A. altissima forests, which suggested that leaf was more sensitive to changes in PRE (Schreeg et al. 2014), thus, plants that grew in relatively infertile soils could translocate more P nutrient from leaves to storage before litter fall (Hayes et al. 2014), resulting in the change of resorption efficiency. When the nutrients are insufficient and cannot be supplemented, the nutrient supply of the system will become the main factor restricting the growth of plants sooner or later. The nutrient resorption efficiency of plants growing in this habitat is low, which indicates that the preservation capacity of $\mathrm{N}$ and $\mathrm{P}$ nutrients of plants is reduced, plants showed a declining trend in nutrient conservation. Our results revealed that $\mathrm{P}$ deficiency was the leading factors, in terms of nutrients, adaptive $\mathrm{P}$ addition strategies may need to be considered to improve P-limitation status. In addition, for the tree species selection, it is a feasible method that selecting proper low $\mathrm{P}$ tolerance breedings in establishment of plain afforestation in future.

\section{Conclusions}

R. pseudoacacia, S. matsudana, and $A$. altissima are common tree species in Beijing plain afforestation area. Identifying their mechanisms for adapting to the plain habitat can provide a theoretical basis for selecting suitable plants for this region. The low N:P ratios of these species are indicative of the fact that the growth of $R$. pseudoacacia and $S$. matsudana was mainly limited by P. The $\mathrm{N}$ and $\mathrm{P}$ in the fresh leaves of $R$. pseudoacacia were significantly higher than those in the fresh leaves of $S$. matsudana and A. altissima, indicating that the NRE of $R$. pseudoacacia was higher. However, the PRE was correlated with the leaf P nutrients in the R. pseudoacacia and $A$. altissima forests. These findings demonstrated that leaf P stoichiometry and PRE were more responsive indicators for plain afforestation area of Beijing. We thus detected patterns of leaf nutrient stoichiometry and resorption among the three studied forests, which have important implications for P fertilizer should be added in a timely way to meet the nutritional needs. Future research should address the longterm effects of different forest management practices on tree $\mathrm{C}, \mathrm{N}$, and $\mathrm{P}$ stoichiometry and to gain a better understanding of the temporal dynamics of NuRE in intensively managed plantations. Furthermore, appropriate forest management strategies should be considered to improve P-limitation status of the Beijing plain plantation ecosystems.

\section{Acknowledgments}

This work was funded by the National Natural Science Foundation of China (Grant No. 31901306). We would like to thank all people contributing to forest plot survey for this study.

\section{References}

Ågren G.I., 2008. Stoichiometry and nutrition of plant growth in natural communities. Annu. Rev. Ecol. Evol. Syst. 39: 153-70. https://doi.org/10.1146/annurev. ecolsys.39.110707.173515

Amazonas N.T., Martinelli L.A., Marisa de C.P., Rodrigues R.R., 2011. Nitrogen dynamics during ecosystem development in tropical forest restoration. Forest Ecol. Manage. 262: 1551-1557. https://doi.org/10.1016/j. foreco.2011.07.003

Boddey R.M., Peoples M.B., Palmer B., Dart P.J., 2000. Use of the $15 \mathrm{~N}$ natural abundance technique to quantify biological nitrogen fixation by woody perennials. Nutrient Cycling in Agroecosystems 57(3): 235-270. https://doi.org/10.1023/A:1009890514844

Cleveland C.C., Houlton B.Z., Smith W.K., Marklein A.R., Running S.W., 2013. Patterns of new versus recycled primary production in the terrestrial biosphere. PNAS 110: 12733-12737. https://doi.org/10.1073/ pnas. 1302768110

Cui Y.P., Liu J.Y., Qin Y.C., Dong J.W., Zhang S.S., 2015. The impact of urban sprawl on heat island intensity in Beijing. Chinese Journal of Ecology 34 (12): 34853492.

Du B.M., Ji H.W., Peng C., Liu X., Liu C., 2017. Altitudinal patterns of leaf stoichiometry and nutrient resorption in Quercus variabilis in the Baotianman Mountains, China. Plant Soil 413: 193-202. https://doi. 
org/10.1007/s11104-016-3093-9

Elser J.J., Sterner R.W., Gorokhova E., Fagan W.F., Markow T.A., Cotner J.B., Harrison J.F., Hobbie S.E., Odell G.M., Weider L.W., 2010. Biological stoichiometry from genes to ecosystems. Ecol Lett 3(6): 540-550. https://doi.org/10.1046/j.1461-0248.2000.00185.x

Elser J.J, Acharya K., Kyle M., Makino W., Markow T., Watts T., Hobbie S., Fagan W., Schade J., 2003. Growth rate-stoichiometry couplings in diverse biota. Ecol Lett 6: 936-943. https://doi.org/10.1046/j.14610248.2003.00518.x

Güsewell S., 2004. N:P ratios in terrestrial plants: Variation and functional significance. New Phytologist 164(2): 243-266. https://doi.org/10.1111/j.14698137.2004.01192.x

Güsewell S., 2005. Nutrient resorption of wetland graminoids is related to the type of nutrient limitation. Funct. Ecol. 19: 344-354. https://doi.org/10.1111/ j.0269-8463.2005.00967.x

Gyenge J., Fernández M.E., 2014. Patterns of resource use efficiency in relation to intraspecific competition, size of the trees and resource availability in ponderosa pine. Forest Ecol. Manage. 312: 231-238. https://doi. org/10.1016/j.foreco.2013.09.052

Hayes P., Turner B.L., Lambers H., Laliberté E., Bellingham P., 2014. Foliar nutrient concentrations and resorption efficiency in plants of contrasting nutrientacquisition strategies along a 2-million-year dune chronosequence. J. Ecol. 102: 396-410. https://doi. org/10.1111/1365-2745.12196

Houlton B.Z., Ying P.W., Vitousek P.M., Field C.B., 2008. A unifying framework for dinitrogen fixation in the terrestrial biosphere. Nature 454: 327-330. https://doi. org/10.1038/nature07028

Kobe R.K., Lepczyk C.A., Iyer M., 2005. Resorption efficiency decreases with increasing green leaf nutrients in a global data set. Ecology 86: 2780-2792. https://doi. org/10.1890/04-1830

Koerselman W, Meuleman A.F.M., 1996. The vegetation $\mathrm{N}: \mathrm{P}$ ration: A new tool to detect the nature of nutrient limitation. Journal of Applied Ecology 33(6): 14411450. https://doi.org/10.2307/2404783

Killingbeck K.T., 1996. Nutrients in senesced leaves: keys to the search for potential resorption and resorption proficiency. Ecology 77: 1716-1727. https://doi. org/10.2307/2265777

Liu Q.M., Wu L.J., Jia S.P., Na Z., Jing Z., Liu B., Qiang F., 2015. Effects of thinned plantation in green passageway of Beijing plain on growth of trees. Protection Forest Science and Technology 155(5): 12-15.

Luyssaert S., Staelens J., De Schrijver A., 2005. Does the commonly used estimator of nutrient resorption in tree foliage actually measure what it claims to? Oecologia 144: 177-186. https://doi.org/10.1007/s00442-0050085-5

Paul K.I., Polglase P.J., Nyakuengama J.G., Khanna P.K., 2002. Change in soil carbon following afforestation. Forest Ecol. Manage. 168(1-3): 241-257. https://doi.
org/10.1016/S0378-1127(01)00740-X

Pugnaire F.I., Chapin III F.S., 1993. Controls over nutrient resorption from leaves of evergreen Mediterranean species. Ecology 74(1): 124-129. https://doi. org/10.2307/1939507

Reich P.B., Oleksyn J., 2004. Global patterns of plant leaf $\mathrm{N}$ and $\mathrm{P}$ in relation to temperature and latitude. Proceedings of the National Academy of Sciences of the United States of America, 101(30): 11001-11006. https://doi.org/10.1073/pnas.0403588101

Rejmánková E., 2005. Nutrient resorption in wetland macrophytes: comparison across several regions of different nutrient status. New Phytol. 167: 471-482. https://doi.org/10.1111/j.1469-8137.2005.01449.x

Reed S.C., Townsend A.R., Davidson E.A., Cleveland C.C., 2012. Stoichiometric patterns in foliar nutrient resorption across multiple scales. New Phytol. 196: 173180. https://doi.org/10.1111/j.1469-8137.2012.04249.x

Schreeg L.A., Santiago L.S., Wright S.J., Turner B.L., 2014. Stem, root, and older leaf N:P ratios are more responsive indicators of soil nutrient availability than new foliage. Ecology 95: 2062-2068. https://doi. org/10.1890/13-1671.1

Sterner R.W., Elser J.J., 2002. Ecological stoichiometry: The biology of elements from molecules to the biosphere [M]. Princeton, N.J.: Princeton University Press.

Sun Z.Z., Liu L.L., Peng S.S., 2016. Age-related modulation of the nitrogen resorption efficiency response to growth requirements and soil nitrogen availability in a temperate pine plantation. Ecosystems 19: 698-709. https://doi.org/10.1007/s10021-016-99625

Tessier J.T., Raynal D.J., 2003. Use of nitrogen to phosphorus ratios in plant tissue as an indicator of nutrient limitation and nitrogen saturation. Journal of Applied Ecology 40: 523-534. https://doi.org/10.1046/ j.1365-2664.2003.00820.x

Vergutz L., Manzoni S., Porporato A., Novais R.F., Jackson R.B., 2012. Global resorption efficiencies and concentrations of carbon and nutrients in leaves of terrestrial plants. Ecol. Monogr 82: 205-220. https:// doi.org/10.1890/11-0416.1

Vitousek P.M., 2003. Stoichiometry and flexibility in the Hawaiian model system. In: Melillo J.M., Field C.B., Moldan B. (eds.) Scope 61: Interactions of the major biogeochemical cycles: global change and human impacts. Washington DC: Island Press: 117-134.

Vitousek P.M., Turner D.R., Parton W.J., Sanford R.L., 1994. Litter decomposition on the Mauna Loa environmental matrix, Hawai'i: patterns, mechanisms, and models. Ecology 75(2): 418-429. https://doi. org/10.2307/1939545

Wang C., Jia B.Q., Qie G.F., 2017. Effect and development countermeasures of Beijing plain afforestation. Journal of Chinese Urban Forestry 15(06): 6-11.

Wang Z., Lu J., Yang M., Yang H., Zhang Q., 2015. Stoichiometric characteristics of carbon, nitrogen, and phosphorus in leaves of differently aged lucerne 
(Medicago sativa) stands. Front. Plant Sci. 6, 1062. https://doi.org/10.3389/fpls.2015.01062

Yan B.G., Liu G.C., Fan B., 2015. Relationships between plant stoichiometry and biomass in an arid-hot valley, Southwest China. Chinese Journal of Plant Ecology 39(8): 807-815.

Yan T., Lü X.T., Zhu J.J., Yang K., Yu L.Z., Gao T., 2017. Changes in nitrogen and phosphorus cycling suggest a transition to phosphorus limitation with the stand development of larch plantations. Plant Soil 422: 385396.

Zhang L., Yan E.R., Wei H.X., 2014. Leaf nitrogen resorption proficiency of seven shrubs across timberline ecotones in the Sergymla Mountains, Southeast Xizang. Chinese Journal of Plant Ecology 38(12): 1325-1332.
Yao Z., Baitian W., Meng, L.I., Xu H.W., Xiu Q.D., 2018. Ecological stoichiometric characteristics of carbon, nitrogen, and phosphorus in three forests in the Lüliang Mountainous Area of Shanxi Province. Chinese Journal of Applied and Environmental Biology 24(3): 518-524. Zheng Y.L., Wang H.Y., Xie Y.L., Li X., 2018. Effect of tree species on soil fertility quality in plain afforestation area, Beijing. Science of Soil and Water Conservation 16(06): 89-98.

Zhu J.T., Li X.Y., Zhang X.M., Lin L.S., Yang S.G., 2010. Nitrogen allocation and partitioning within a leguminous and two non-leguminous plant species growing at the southern fringe of China's Taklamakan Desert. Chinese Journal of Plant Ecology 34(9): 1025-1032. DOI: 10.3773/j.issn.1005-264x.2010.09.003 